\section{References}

1 Dathan JG, Harvey CC. Pink disease-ten years after (the epilogue). $\mathrm{Br}$ Med J 1965;i:1181-6.

2 Health and Safety Executive. Occupational exposure limit 1986. London: HMSO, 1986. (Guidance Note EH 40/86.)

3 House RA, Smith H. Mercury in human tissue. J Forensic Sci Soc 1967;7:90-6.

4 Alexander JF, Rosario R. A case of mercury poisoning. Acrodynia in a child of 8. Can Med Assoc J 1971;104:929-30.

5 Moutinho ME, Tompkins AL, Rowland TW, Banson BB,
Jackson AH. Acute mercury vapour poisoning. Am J Dis Child $1981 ; 135: 42-4$.

${ }^{6}$ McNeil NI, Olver RE, Issler HC, Wrong OM. Domestic metallic mercury poisoning. Lancet 1984;i:269-71.

Correspondence to Dr H A Curtis, Department of Child Health, Royal Devon and Exeter Hospital, Wonford, Barrack Road, Exeter EX2 5DW, England.

Received 20 October 1986

\title{
Transient congenital hypothyroidism after topical iodine in pregnancy and lactation
}

\author{
Y DANZIGER, A PERTZELAN, AND M MIMOUNI
}

Department of Pediatrics B, Beilinson Medical Center, Petah Tiqva, and Sackler School of Medicine, Tel Aviv University, Israel

SUMMARY A 6 week old girl with transient congenital hypothyroidism is described. The hypothyroidism was associated with multiple applications of povidone iodine during pregnancy and lactation. This case illustrates the potential hazard of using topical solutions containing iodine during pregnancy and lactation.

Congenital goiter and, rarely, transient hypothyroidism have been reported to occur sporadically in infants whose mothers received iodides during pregnancy for a variety of non-thyroid diseases or hyperthyroidism.

In these cases iodides had generally been taken orally by the pregnant mother. ${ }^{12} \mathrm{~A}$ few cases of congenital transient hypothyroidism secondary to maternal exposure to procedures using contrast media that contain iodine have been described. ${ }^{3}$

We report a case of a prolonged but transient hypothyroidism without goiter in a girl whose mother used povidone iodine preparations during pregnancy and lactation.

\section{Case report}

A 6 week old Jewish girl of Ashkenazi origin, the youngest of five healthy siblings, was referred to our day care unit because of a low serum total thyroxine concentration of $3 \mu \mathrm{g} / \mathrm{dl}$ (normal value $>7 \mu \mathrm{g} / \mathrm{dl}$ ) revealed by routine screening for congenital hypothyroidism. She was born at term after an uneventful pregnancy and delivery. Her birth weight was $4000 \mathrm{~g}$. During the pregnancy the mother washed herself almost daily with a solution of povidone iodine, which is a complex of iodine and polyvinylpyrrolidone, which releases free iodine in solution, with $1 \%$ available iodine. She had also rubbed large areas of her skin with povidone iodine ointment $(1 \%)$ because of spreading furunculosis. These procedures were continued during lactation until referral.

The mother's aunt and uncle suffered from a thyroid disorder, the nature of which could not be elucidated.

Physical examination revealed an infant in good condition with mild jaundice. Her weight was $5 \cdot 1$ $\mathrm{kg}$, length $54.5 \mathrm{~cm}$, and head circumference $40 \mathrm{~cm}$. Body temperature was normal. No goiter was palpable. The face was round with a protruding tongue. Respiration was noisy but there were no signs of respiratory distress. The abdomen was large and the liver was palpated $3 \mathrm{~cm}$ below the costal margin. A large umbilical hernia was present. Neurological examination yielded normal results, except for moderately delayed deep tendon reflexes. Laboratory tests revealed a serum concentration of free thyroxine $0.4 \mathrm{ng} / \mathrm{dl}$ (normal values $0.7-2 \mathrm{ng} / \mathrm{dl}$ ). Thyroid stimulating hormone (TSH) was $99 \mu \mathrm{U} / \mathrm{ml}$ (normal value $0 \cdot 8-5 \mu \mathrm{U} / \mathrm{ml}$ ). Indirect bilirubin was $5.6 \mathrm{mg} \%(95 \mu \mathrm{mol} / \mathrm{l})$. Thyroid antibodies were negative in the child and her mother. A thyroid scan yielded normal results.

A diagnosis of primary hypothyroidism was made on the basis of raised TSH and decreased thyroxine concentrations. Treatment with L-thyroxine sodium was started. On follow up, there was an increase in thyroxine and a decrease in TSH concentrations (Table). 
Table Clinical, laboratory, and pertinent therapeutic data in a case of transient congenital hypothyroidism associated with maternal application of povidone iodine during pregnancy and lactation

\begin{tabular}{|c|c|c|c|c|c|}
\hline $\begin{array}{l}\text { Age } \\
\text { (months) }\end{array}$ & $\begin{array}{l}\text { Weight } \\
(\mathrm{kg})\end{array}$ & $\begin{array}{l}\text { Length } \\
\text { (cm) }\end{array}$ & $\begin{array}{l}\text { Free } \\
\text { thyroxine } \\
(\text { ng/dl) }\end{array}$ & $\begin{array}{l}\text { Thyroid } \\
\text { stimulating } \\
\text { hormone } \\
(\mu \mathrm{U} / \mathrm{ml})\end{array}$ & $\begin{array}{l}\text { Treatment with } \\
\text { L-thyroxine sodium } \\
(\mu g)\end{array}$ \\
\hline $1 \cdot 5$ & $5 \cdot 1$ & $54 \cdot 5$ & $0 \cdot 4$ & 99 & $50 /$ day \\
\hline 2 & $5 \cdot 5$ & $56 \cdot 5$ & $3 \cdot 5$ & $5 \cdot 7$ & $50 /$ day \\
\hline $2 \cdot 75$ & $6 \cdot 0$ & 59.6 & 3.4 & 1.5 & $25 /$ every two days \\
\hline 5 & $7 \cdot 0$ & 62 & $2 \cdot 1$ & 1.5 & $25 /$ every two days \\
\hline 7 & 8.0 & $66 \cdot 5$ & 1.6 & $3 \cdot 3$ & $25 /$ every two days \\
\hline $8^{*}$ & - & - & $1 \cdot 8$ & $2 \cdot 7$ & - \\
\hline 12 & $10 \cdot 8$ & 74 & & Discharge & \\
\hline
\end{tabular}

*Bone age 6 months (according to Greulich and Pyle).

Growth and psychomotor development were normal. Treatment was stopped at the age of 7 months. At 1 year growth and development were normal.

Pertinent clinical and laboratory data are summarised in the Table.

\section{Discussion}

Iodide inhibits biosynthesis and secretion of thyroid hormones if a certain threshold is reached in the serum. ${ }^{1}$ Iodide readily crosses the placenta. ${ }^{3}$ Transient congenital hypothyroidism with or, rarely, without goiter has been reported to occur sporadically in infants whose mothers ingested iodides during pregnancy for asthma or hyperthyroidism. ${ }^{12}$ Other cases have occurred after various procedures, such as intravenous pyelography, amniofetography, ${ }_{3}$ or topical application of iodine solution during labour or delivery. ${ }^{45}$

To our knowledge no case of transient congenital hypothyroidism due to topical application of iodine by the pregnant mother has been reported. Our case illustrates the potential hazard of topical iodine during pregnancy. The use of iodides should also be prohibited during lactation because the iodide is readily secreted into the milk. ${ }^{1}$

Impairment of thyroid function due to iodides is transient. After withdrawal thyroid function returns to normal within two to six weeks. ${ }^{1}$ In cases of congenital hypothyroidism replacement therapy should be started to avoid brain damage, even if it is thought that the hormonal impairment might be transient.

In this instance the mother stopped iodide ap- plications, and we encouraged the continuation of breast feeding and began treatment with Lthyroxine. This treatment should be carefully monitored by clinical and laboratory tests. In previously reported cases of transient congenital hypothyroidism replacement therapy has been stopped after a few months, even though thyroid function returns to normal much earlier. As povidone iodine is a common topical antiseptic, not always considered by the mother as a drug, this may explain the aetiology of cases of transient congenital hypothroidism with high serum and urine concentrations of iodine that have been reported. ${ }^{6}$ Topical iodine products should be avoided during pregnancy and lactation.

\section{References}

1 Wolff G. Iodide goiter and the pharmacologic effects of excess iodide. Am J Med 1969;47:101-11.

2 Job JC, Bocquentin F, Canlorbe P. Les goitres du nouveau né. Arch Fr Pediatr 1974;31:127-36.

${ }^{3}$ Rodesh F, Camus M, Ermans AM, Dodion J, Delange F. Adverse effect of amniofetography on fetal thyroid function. Am J Obstet Gynecol 1976;126:723-6.

${ }^{4}$ Theodoropoulos T, Braverman LE, Vagenakis AG. Iodideinduced hypothyroidism. A potential hazard during perinatal life. Science 1979;205:502-3.

${ }^{5}$ L'Allemand D, Groters A, Heidemann P, Schurnbrand P. Iodine-induced alterations of thyroid function in newborn infants after prenatal and perinatal exposure to povidone iodine. J Pediatr 1983;102:935-40.

6 Delange F, Dodion J, Wolter R, et al. Transient hypothyroidism in the newborn infant. $J$ Pediatr 1978;92:974-6.

Correspondence to Dr M Mimouni, Department of Pediatrics B, Beilinson Medical Center, Petah Tiqva, 49 100, Israel.

Received 18 August 1986 